Article

\title{
Sustainable Environmental Management Indicators in South African Primary Schools
}

\author{
Luiza O. de Sousa *, Barry W. Richter and Schalk P. Raath \\ Geography Education \& Environmental Education, North-West University, Potchefstroom 2520, South Africa; \\ Barry.richter@nwu.ac.za (B.W.R.); Schalk.raath@nwu.ac.za (S.P.R.) \\ * Correspondence: Luiza.desousa@nwu.ac.za; Tel.: +27-018-299-4727
}

Academic Editor: Kerry Shephard

Received: 23 March 2017; Accepted: 12 May 2017; Published: 19 May 2017

\begin{abstract}
This research explores sustainable environmental management indicators in South African primary schools. Of key interest is the comparison of a township, farm and urban primary school that identify indicators that promote education for sustainable development in schools that implement an environmental management system. Data are drawn from one-on-one interviews, focus group interviews, observations and document analysis from 35 participants in three schools. A comparison of the three schools was done by content and thematic analysis of a within-case analysis. Data from the township school revealed that socioeconomic factors and organisational structure promote education for sustainable development. The farm school data revealed that health promotion can be managed within an environmental management system within a hierarchical school structure. The urban school data revealed that an economic inducement brings a school to realise that it can reduce its carbon footprint, gain financially and utilize its resources with innovation. A case is made that the four pillars of sustainable development (environment, society, economy, and governance) endorse education for sustainable development. Furthermore, the objectives of environmental education ought to remain nested in an environmental management system to ensure that the global goal of quality education is achieved.
\end{abstract}

Keywords: education for sustainable development; environmental management system; primary school governance; socioeconomic environmental management indicators; systems theory; within-case analysis

\section{Introduction}

Education that promotes lifelong learning plays a vital role in influencing positive change in society and in the environment through school governance. Limited literature exists on how to teach about sustainable development [1]. Schools have the capability to highlight the importance of the environment by implementing sustainable living practices that can be practiced beyond the classroom. Research was deemed necessary in a primary school's environmental management, especially since effective preventative models of environmental management aimed at sustainable development are highly recommended [2]. Furthermore, a behavioural intervention (instrumental approach) assumes that a desired behavioural outcome can be achieved, for example, with the intervention of an environmental management system [3]. This research originated from a collaboration between the Faculty of Education Sciences of a South African university and a university in Belgium. The project introduced to interested primary schools in South Africa an environmental management system, with adapted themes, from Belgium's Milieuzorg Op School (MOS) [Environmental Care at School]. In order to represent the South African landscape, a township, farm and urban school were chosen because, like many other schools in South Africa, they have rural or urban environments that are constantly changing, leaving their leaders and management facing challenges [4]. The township 
school refers to an urban settlement for African people that still exists on the outskirts of towns and cities as a settlement planned for people classed as black or of mixed ethnic origin by the apartheid system [5]. The farm school chosen is located on community-owned farming land and not a commercial farm. The urban school refers to a school found in a city's residential suburb. The main aim of the project was to introduce, implement and monitor an environmental management system in primary schools that is specific to an African primary school context [6], and to have a practical trans-curricular approach to educating for sustainable development that would be an integral and integrated part of a school's management and curriculum activities [7]. In this way transformative governance towards integrated school sustainable management of natural resources can address the sustainable development goals [8,9] in a developing country.

\section{Problem Statement}

The questions guiding this research were: What key indicators of an environmental management system can be identified in a township, farm and urban primary school? What should an environmental management system framework look like to promote education for sustainable development in three South African primary schools? The term indicator was used to communicate the summary of observations undertaken in the schools that provided insight into how the schools implemented their environmental management system. In effect the indicators operationally describe the intended output or outcome that the school aimed to achieve over time $[10,11]$.

\section{Literature Review}

The subject of environmental governance has been addressed by the Constitution of South Africa in the form of a framework that incorporates the right to an environment that is not harmful to the health and wellbeing of its citizens [12]. The National Environmental Management Act (NEMA) stipulates the important issue of environmental management and acknowledges that a human-environment relationship exists that is central to management [13]. Environmental ethics ought to direct school management toward the implementation of environmental management, since the environment ought to be considered in all elements of school life ranging from teaching and learning to management.

The universal sustainable development goal (number 4) that requires learners to acquire the knowledge and skills needed to promote sustainable development is an achievable goal through the implementation of an environmental management system [9]. This is a management tool for a whole-school approach and education for sustainable development. In a school context it is "a systematic, coherent set of measures and provisions intended to: quantify, prevent and, where possible, limit the amount of pollution generated by the school" [14] (p. 907). Environmental management system practices in primary school contexts have been reported for a developing (South Africa) and a developed (Belgium) country [14,15]. An environmental management system is a method of incorporating environmental care throughout an organisational structure, using a systematic process [16-18] to implement environmental goals, policies and responsibilities together with regular auditing of its elements $[17,19]$. An environmental management system is recommended within the World Summit on Sustainable Development's Summit Plan of Implementation to improve social and environmental performance [20], and nations have implemented their own programmes to meet the recommendation.

The Belgian MOS project is an environmental management system for schools started in 2001 with the principle objective to raise a learner's awareness of environmental issues through the school's own environment [21]. The school's projects are assessed by a jury every school year. Schools are encouraged to develop long-term projects that entrench environmental awareness in school policy [22]. Internationally, the Eco-Schools Programme for schools aims to promote sustainable development by implementing environmental education within the formal school education system's curriculum and by the training of staff $[23,24]$. Eco-Schools aim to raise awareness among learners about sustainable 
environmental development issues and follow a holistic, participatory approach that combines learning and action. Eco-Schools is committed to improving the environmental performance at the school by using an environmental management system at a school, based on an ISO14001 and Eco-Management and Audit Scheme approach $[23,24]$. The United Kingdom's sustainable school initiative is the result of the first Education Sustainable Development Action Plan published in 2003. This initiative takes an integrated approach to improving a school and prepares young people for a lifetime of sustainable living through its teaching and learning (curriculum), values and ways of working on the school site, and involvement of the local community $[25,26]$.

In Germany the federal government declared that EE was an indispensable element of a precautionary policy to protect nature and the environment. The German BLK "21" Programme (State-Federal States Commission for Educational Planning and Research Promotion [BLK]) supported the introduction of education for sustainable development into schools from 1999 to 2004. It introduced interdisciplinary approaches, cooperative structures between educational organisations and authorities, anticipatory thinking, networked thinking, the ability for solidarity, thoughts on visionary and utopian concepts, and the promotion of creativity and imagination $[27,28]$. Due to the independent nature of 16 German federal states' responsibility toward educational policies, various programmes have been initiated: for example, the Association of Environmental Education Centre's ANU 2000 project that advised environmental educational organisations all over Germany with regard to education for sustainability and helped them meet the requirements for the new tasks at hand [27]; the 2007/2008 Hands-On Innovations, Technology and Sustainability pilot project to facilitate the integration of education for sustainable development into the curricula and help the learners gain specialised knowledge, gain insights, communicate and evaluate facts $[29,30]$; and the Hamburg Learns Sustainability initiative of 2005 to promote integration of the guiding principle of sustainable development in all areas of education [31].

In this research the implementation of an environmental management system at schools involved a whole-school approach to achieving education for sustainable development by means of curriculum and management practices $[32,33]$ and was based on the general management strategies of the Deming Management Model and the Deming cycle's principles that state that any management process may include planning, doing, checking and acting elements [34]. Environmental management demands a multidisciplinary, interdisciplinary or even holistic approach [35], reiterated in the principles of environmental education [36]. The management and practice of formal education has led to the establishment of whole-school programmes. Here the focus is on school development underpinned by the whole-school approach to sustainable development $[37,38]$. The significance of environmental education and education for sustainable development is explored further.

Since its inception in the 1970s, environmental education was not accepted as a concept in its own right, but instead was spread across a diversity of disciplines that used the environment as a vehicle for teaching. Throughout the 1980s environmental education took on an apolitical and naturalist character. In the 1990s environmental education became concern with the environment and development problems. This meant greater support for an educational approach that considered immediate environmental improvement as an actual objective [39]. Environmental education continues to highlight the importance of natural resources (water, energy, agriculture, and biodiversity) and encourages behaviour that protects the world's natural resources [40]. Environmental education was defined by UNESCO as "a well-established discipline which focuses on humankind's relationship with the natural environment and on ways to conserve and preserve it and properly steward its resources" [41] (p. 16). Environmental education is central to education for sustainable development and the roots of education for sustainable development are firmly planted in environmental education [37]. Sustainable development is the ultimate aim of environmental education, affirming that environmental education is closely associated with sustainable development [42]. The Intergovernmental Conference on Environmental Education for Sustainable Development held in Tbilisi in 2012, thirty-five years since the publication of the Tbilisi Declaration 
(Tbilisi+35) recognised that "environmental education processes support and champion education for sustainable development". Tbilisi+35 called on governments to support environmental education within sound education for sustainable development policy frameworks [43] (p. 1), showing that environmental education is not in danger of disappearing. Education for sustainable development is defined as encompassing "Environmental education, setting it in the broader context of socio-cultural factors and the socio-political issues of equity, poverty, democracy and quality of life" [41] (p. 16).

The influence of the United Nations (UN) in promoting a whole-school approach as an active integration of sustainable development into education $[9,38,44]$ has ensured that a holistic education teaches learners about understanding the environment as connected and integrated. This cultivates a curriculum of connections. The connections include systems thinking as a form of thinking and making connections to the earth and its processes as an essential characteristic of education for sustainable development [45].

Learning to think systemically is critical in education for sustainable development [46] and may be a fundamental guiding principle towards effective education for sustainable development. Teachers, learners and school management may begin to think systemically through their management and curriculum duties [47]. Cloud [48] is of the opinion that one cannot teach about sustainability without teaching about systems thinking and its dynamics. Whole systems thinking [25] is a combination of different philosophical beliefs, including systems thinking and ecological thought. It has a holistic and ecological epistemology that is related to a whole-school approach. The philosophical basis of the ecological educational paradigm is moulded by the "nesting and interrelated systems" framework of education paradigms [49] (pp. 105, 116, 231, 263-268) [50] (p. 67). This means that what an organisation like a school does (educational praxis) is ultimately informed by its dominant view of reality (educational eidos ethos/policy/theory) and its significant paradigm that refers to the way of knowing and sense of purpose (educational ethos).

Bronfenbrenner, a leader in the systems approach [51,52], identifies how systems (microsystems, mesosystems, exosystems, macrosystems, and chronosystems) can positively or negatively influence individuals [53]. Communities and social institutions are required to work at developing connections between the systems. This will mean greater positive influences on families and individuals [47]. In light of this theory, this research finds that developing connections between systems to ensure that exposure to environmental learning and management in South African primary schools can promote sustainable development.

A common critique levelled against Bronfenbrenner is that his systems theory does not refer to the biophysical environment that all individuals find themselves in. By exposing learners to a whole-school approach, education for sustainable development teaches people to actively interact with the environment and develop an awareness of sustainable living as they mature and develop a value system [47]. Bronfenbrenner's theory was applied to this research since it helps us to understand the whole system and its interactions, which is necessary for understanding the parts of the system and the interaction between them. This theory was applied to a school as an organisation that has implemented an environmental management system. Firstly, the stakeholders in a school are influenced by the interacting and complex system of relationships between themselves and the curriculum. Secondly, an interactive and complex system of relationships exists between the stakeholders who function as part of the environmental management system and the school environment.

Management theories are also embedded in human psychology. They focus on individual participants and form part of a complex, interrelated, interdependent structure embedded in systems theory [54,55]. A school, as an organisation, can adapt the management of its environment and needs to be aware of the impact of its socioeconomic situation on the practicality of, for example, experiential learning due to the number of learners in the class. Research has found that teachers struggle to deal with complex issues in isolation. However, the complex nature of sustainable development brings the whole school community together and involves teachers in matters of environmental learning [38] so that connections and complex interrelationships may be made. By initiating such human development 
(an emancipatory approach) the whole school community can engage in active dialogue. This will establish co-owned objectives and a joint plan of action to make changes that the school as a whole considers necessary and that can contribute to a more sustainable society as a whole. Such an approach will require a more systemic and reflexive way of thinking and acting [3].

Environmental management system organisational barriers require attention. These include organisational structure, top management commitment, lack of communication in environmental management system implementation, organisational culture, strategy integration, strategy complexity, and management style. It is strongly suggested that when an environmental management system is implemented, change management skills, learned through experience, must be applied $[47,54]$, since a yearly evaluation will direct the school's focus and allow it to adapt to new ways of operating. It will make schools grow in knowledge and skills acquisition and change the learners' experiential learning activities. All the stakeholders could apply systemic and holistic thinking practices to their duties to establish cause and effect. In this way a relationship will exist between systems theory and the implementation of an environmental management system into a school organisation as a system [47].

\section{Research Design and Methods}

This qualitative multiple case study research study relied on purposive sampling to select participants who are involved with teaching and learning, management, and the daily operations at each school. Data were generated using document analysis, non-participant observations, one-on-one interviews and focus group interviews undertaken with participants who are stakeholders in each of the three schools, and were analysed using content and thematic analysis [56,57] of all the interviews to identify issues or themes.

\subsection{Methodology}

The purpose of this qualitative study was to identify key indicators of an environmental management system after understanding how an environmental management system is implemented at a farm, township and urban school, respectively, representing different primary schools in South Africa. The whole school was involved to identify indicators that contributed to the three primary schools' implementation of an environmental management system to promote education for sustainable development. The indicators helped to design an environmental management system framework for these schools. The research methodology included a multiple case study research design [58]. This study required an analysis of the curriculum to explore how the environment is presently integrated in the teaching and learning of the curriculum to promote education for sustainable development, and the identification of key indicators of the environmental management system in the township, farm and urban primary school that promote education for sustainable development. A whole-school approach was considered, together with all the stakeholders in a school, to aid in the design of an environmental management system framework to promote education for sustainable development in South African primary schools.

\subsection{Paradigm}

The research of this study is based on the interpretivist epistemology since it aimed to understand how the school following a whole-school approach to promoting education for sustainable development implemented an environmental management system as a system within a school as a system. The researchers assumed the role of idealists who, in trying to understand how an environmental management system is implemented at three different primary schools in South Africa when undertaking an interdisciplinary approach to teaching about the environment, were dependent on a hermeneutic understanding and interpretative factors. 


\subsection{Sampling Strategy}

Purposive sampling was applied when choosing the three schools since it was a requirement that each of the selected schools have a working environmental management system. The study focused on each primary school's environmental management system, as well as the teaching and learning at the school that promoted education for sustainable development from Grade R (reception year) to Grade 7 according to the curriculum. The three schools chosen were deemed information-rich cases for an in-depth study of the environmental management system. The criteria were that the schools be exemplar cases, all primary schools, had to have a unique situation (located in a township, on a farm, and in an urban area), and chosen from the North West and Gauteng provinces. A township school refers to a school in an urban settlement for African (Statistics South Africa describes the population groups in the country as African, Coloured, Indian/Asian and White [59].) people that still exists on the outskirts of a town or city as a settlement planned for people classed as black or of mixed ethnic origin by the apartheid system [5]. The school services the township community, which is dependent on work from the mine, light industry and retail, but unemployment is high. The farm school chosen is located on community-owned farming land and not a commercial farm. The school only provides primary education and the learners are the children of African and Coloured farm workers. The urban school chosen in this research refers to a school found in a city's residential suburb. The school learners are from the African, Coloured and White population groups.

A pilot study that was undertaken at a school in the Free State province helped clarify the sampling strategy and supports the trustworthiness of this research. It was established from the pilot study that staff from the administration block, representative teachers from each phase, cleaners and ground staff all needed to be interviewed as well, so as to establish how the environmental management system was implemented. The pilot study also highlighted the fact that purposeful selection instead of random selection of participants was necessary so as to gain the most knowledgeable responses [56]).

In this multiple case study research all the stakeholders at each school formed the participants. The participants were deliberately selected as being the best representatives who could share their knowledge and experience of environmental management, teaching and learning. Each case study's participants differed in number due to their unique situations. The data were collected from the headmaster, a member of the governing body, community, cleaning staff, gardening staff and administration staff, an environmental committee coordinator, a Foundation phase, Intermediate phase, and Senior phase teacher, and learners representative of the Intermediate and Senior phase grades. The participants interviewed in each of the three schools are tabulated below (cf. Table 1).

Table 1. Participants interviewed and methods of data collection in the township, farm and urban school.

\begin{tabular}{cccc}
\hline & Township School & Farm School & Urban School \\
\hline Role & $\checkmark$ & & $\checkmark$ \\
\hline Administration member & $\checkmark$ & $\checkmark$ & $\checkmark \checkmark$ Photocopy maker \& cleaner \\
\hline Cleaner & $\checkmark$ & $\checkmark$ & \multirow{2}{*}{ Intermediate \& Senior phase } \\
\hline Environmental co-ordinator & $\checkmark$ & $\checkmark$ & $\checkmark$ \\
\hline Senior phase teacher & $\checkmark$ & $\checkmark$ & $\checkmark$ \\
\hline Foundermediate phase teacher & $\checkmark$ & $\checkmark$ & $\checkmark$ \\
\hline Community member & $\checkmark$ & $\checkmark$ & $\checkmark$ \\
\hline Governing body chairperson & $\checkmark$ & $\begin{array}{c}\checkmark \checkmark \text { Grounds man \& } \\
\text { vegetable garden } \\
\text { caretaker }\end{array}$ & \\
\hline
\end{tabular}


Table 1. Cont.

\begin{tabular}{cccc}
\hline & Township School & Farm School & Urban School \\
\hline Role & $\checkmark$ & $\checkmark$ & $\checkmark$ \\
\hline $\begin{array}{c}\text { Group of learners representing } \\
\text { the Intermediate and } \\
\text { Senior phases }\end{array}$ & $\checkmark$ & $\checkmark$ & $\checkmark$ \\
\hline Headmaster & 10 & 10 & 10 \\
\hline Method of data collection & 6 & 8 & 7 \\
\hline One-on-one interviews & $\checkmark$ & $\checkmark$ & $\checkmark$ \\
\hline Focus group interviews & $\checkmark$ & $\checkmark$ & $\checkmark$ \\
\hline Observations & & & \\
\hline Document analysis & & $\checkmark$ & \\
\hline
\end{tabular}

\subsection{Methods of Data Collection}

All the one-on-one semi-structured interviews (cf. Table 1) undertaken in this study used open-ended questions. All the participants for these interviews received invitation letters to take part in the study and gave their written consent. Probing yielded in-depth responses about the participants' knowledge of environmental learning and management at the school. The data consist of verbatim quotations with a great deal of context that was interpretable. Participants were asked to answer questions aimed at providing an understanding of how the environmental management system is implemented at the school and how environmental learning takes place there. The same interview schedule was used at all three schools. The discussions were guided by the following main questions: "Thinking within your job description, what has been undertaken at the school that shows that it has become environmentally conscious? Has management ever asked you to be mindful of the environment in your work when dealing with water, waste, energy, and the school gardens? Elaborate when this has happened. Elaborate how it has happened. Elaborate why it has happened." (Administration staff, cleaning staff \& ground staff) "What is your involvement in the school's management of the environment, if any? Elaborate by giving examples." (Community and governing body members) "How do you ensure that environmental learning takes place in your lessons? How was/is planning done for learning inside and outside the classroom? Elaborate by giving examples. What has your experience been with respect to implementing environmental learning into your teaching and learning? Elaborate by giving examples. How have you contributed toward the implementation of the environmental management system in the school? Elaborate by giving examples." (Teaching staff members \& environmental coordinator who is also a teacher) "How was the environmental management system implemented at your school? Elaborate on the process by giving examples. How would you describe your involvement in the school's environmental management system aimed at promoting education for sustainable development? Elaborate by giving examples" (Headmaster).

The learner participants (girls and boys) who took part in the focus group interviews were asked to answer questions by having a discussion with one another, facilitated by the researcher, in order to provide an understanding of how the environmental management system is implemented at the school and how environmental learning takes place there. Participants from the farm school were reserved and did not converse easily with each other. Twenty-one learners in total participated in the focus groups across the three schools. The focus group interviews were conducted separately at each school. The discussions were guided by the following main questions: "What have you learnt at school about the environment? In what context(s) was this learnt? Tell me more about what you have learnt in class during a lesson about how to live sustainably. Give me examples from this year. Tell me more about what you have learnt outside of a class during a lesson about how to live sustainably. Give me examples from this year." 
Observations in this study refer to descriptions of activities, actions, interpersonal interactions and other observable human experiences in the classroom and on the school property. The data for this study consist of rich field notes, detailed descriptions, including the content within which observations were made, and audio recordings. The first-hand observations undertaken were comprised of two parts. Firstly, non-participant observations took place in the Foundation phase classrooms. The observations of a non-participant during class time helped confirm and refute whether and how environmental learning was dealt with. Being mindful of the observer effect, it was prearranged that the researchers could visit any of the Foundation phase classrooms at any time without prior notification. An open-ended format was used to record what was considered significant. It was not deemed necessary to review lesson plans and work schedules of the teachers since the teacher is required by the national curriculum to do so. A literature analysis of the curriculum and the interviews were deemed sufficient to establish how environmental learning takes place at the school.

A non-participant observation of the school premises was undertaken to establish how the school premises (classrooms, outbuildings, yard, fields and gardens) reflect education for sustainable development. A reflective summary was given at the end of the observation, identifying characteristics specific to each type of school. Another aim of the observation was to identify indicators that shed light on how the school premises promote education for sustainable development. The physical setting, the participants, activities and interactions, visible conversations between people in the context and nonverbal behaviour, informal and unplanned activities, as well as the role of the observer in the scene were noted.

Documents used in this study included written material and other documents (reports, records, photographs, and newsletters) from the school. The data consisted of excerpts from documents captured in a way that records and preserves context. A document analysis was undertaken of the components of the environmental management system implemented by each of the three schools in the case study, found in the documentation of the headmaster or environmental committee coordinator, since each school adopted an environmental management system to suit their specific circumstances. Access to the relevant documents of the schools required patience and ethical care. Some schools were reluctant to share their files. Copies of documents were permitted and care was taken to note dates, context, status of documents, and sensitivity of documents. Information not presented after a request was handled sensitively during the interviews. Cognisance was taken of the authenticity and accuracy of documents as part of the research process, for example, minutes of meetings, reports, newsletters, agreements, the written declaration of commitment to the environmental management system, environmental policy, decisions taken regarding the chosen environmental themes for the school, the action plan, school newsletters, a copy of the school's environmental objectives and targets; how the action plan is implemented and maintained, the evaluation mechanism and procedures in place. The independence of the documents, the fact that they were not altered by human motives, made them non-reactive and a beneficial data source $[56,60]$. The non-participant observations in the Foundation phase classrooms and the non-participant observation of the school premises took place between interviews and during the course of the four days. The observations were first done unaccompanied and then accompanied by the environmental committee coordinator. The duration of time between each school case research was a minimum of a few days and a maximum of two weeks.

\subsection{Methods of Data Analysis}

For the purpose of this study, inductive inference was used when dealing with the within-case analysis of three cases in this study to establish how environmental learning is integrated in the township, farm and urban primary schools to promote education for sustainable development and to identify indicators of the environmental management system implemented at the three schools. Conclusions could be drawn about how the environmental management system is implemented in the three schools and their situation [61], but not generalisations. The interpretation of the results comprised content analysis of all the interviews that were analysed by establishing categories 
(coding) and then interpretation of the data in terms of common themes [61]. Within-case coding and categorising of the data took place for each of the three cases. The thematic clusters obtained by concept analysis of the interviews, observations and document analysis [62] were compared and showed similarities, as well as significant differences between the schools' environmental management system. Collaborative coding was used. Three coders read and coded the transcribed data sets to ensure trustworthiness, rigor and quality. The main researcher decided to use two coders for investigator triangulation [63]. The three coders collaborated on concept meaning where there were discrepancies in the interpretation of the data [62]. A codebook was compiled to list and define codes. As the process of code mapping evolved the codes were reviewed [62]. The compilation of codes in the codebook was completed until saturation of codes was reached. As part of the validation process, saturation was reached when the coding of the new data did not yield new themes, but reaffirmed existing codes and categories [62,64]. When reviewing the indicators identified in each school the coders realized that since sustainable development is the ultimate aim of environmental education the indicators could be clustered accordingly [42]. A sixth category of evaluation was added since it features strongly as a recommended feature of an environmental management system.

Bias and subjectivity were minimised [65] through the recording of all the interviews and member-checking that took place contributing to participant validation [66]. The pilot study and multiple data collection method added to the trustworthiness and credibility of data collection methods $[65,66]$. The extent to which this research's findings can be applied to other situations is known as its generalisability [56]. However, this qualitative study was not generalisable in its purpose; rather, it served the purpose of generating an in-depth, holistic and situated understanding of the phenomenon. In this study triangulation was established through multiple data collection methods that included interviews, observations and documentation. Multiple participants were also used so as to collect multiple viewpoints from all the participants in the school about the same topic $[56,65]$.

\subsection{Ethical Considerations}

Prior to the data collection, permission was requested from and granted by the North West and Gauteng Provincial Departments of Education, as well as from the three school headmasters after personal meetings. Invitation letters and consent forms were issued to the participants by the environmental committee coordinator. All participants presented their letters of consent before the interviews commenced. Prior to the beginning of the interviews (one-on-one interviews for one member of the governing body, a teaching staff member, an administration staff member, a garden staff member and a cleaning staff member, and a community member/parent involved at the school, as well as the headmaster and the environmental committee coordinator; the focus group interview at each school was undertaken with learners representing Grades 4 to 7 and was made up of both boys and girls), the aim of the research was communicated to the participants. This was followed by participants providing biographical information serving the purpose of establishing how long the participants had been at the school, how long they had been in the profession and what exactly their function was at the school. The focus group interviews began by explaining to the learners that they were to engage in a facilitated discussion with each other. The aim of the research was explained to them, as well as the consent form that they signed. Parents and learners received invitation letters to take part in the study. Consent from parents and assent from learners were obtained.

\section{Results}

The analysis of the one-on-one and focus group interviews, non-participant observations and document analysis regarding the integration of environmental learning is presented and discussed separately for the township, farm and urban school by means of a within-case analysis. Interviews were conducted separately with the participants at each of the three schools. The unit of analysis is a multiple-case holistic design using a within-case analysis. The multiple-case study showed how the implementation of an environmental management system is dependent on a whole-school 
approach since all the stakeholders are required to be knowledgeable and part of the environmental management system.

The data analysis shows that in the township school caring for plants, a low tolerance of littering and the upkeep of cleanliness and hygiene are bases for understanding environmental learning, as a learner shared "... learn how to take care of our environment. It means that we should not litter and plant trees to make our planet more lively". In the teaching and learning of Life Orientation, Social Sciences, Natural Sciences ("Natural Sciences teaches about plants. Sometimes we go out in the yard and through the garden. And our teacher ... she would pick up flowers and give us examples... tell us what should we do for the plants to grow."), English, Sepedi and Life Skills as subjects where the environment is a focus, the reinforcement to save water and electricity and to maintain hygiene has moved beyond the classroom, indicating that learners have been exposed to education for sustainable development. This has been aided by experiential learning using the indigenous and vegetable gardens in the school. The presence of a Soul Buddyz club (a club aimed at eight- to 14-year-olds that engages in social activities) that reinforces care for the environment has also contributed to education for sustainable development. The inclusion of environmental learning remains an issue with regard to who is the responsible party for its inclusion in teaching and learning. The interpretation is that everybody is responsible for it in his/her subject. However, there are two hindrances to the inclusion of environmental learning: If it is not included in the curriculum and if it is not an order from the district office of the department of basic education who mandates its inclusion, then time constraints, due to large learner numbers in classes, are named as limiting factors for its inclusion ("Sometimes it becomes difficult to include the extra things because we work all day and ... I have 64 learners...").

In the farm school caring for the biosphere is the basis of environmental learning among learners and the environmental coordinator ("I call it the way of life because you have to take care of yourself, the environment you live in, and then, the people who live in it"). It is clear that the farming environment is taken as a point of reference for these learners. The learners indicated that they do occasionally go outside to engage with the environment, but "not so often." Of note is that the learners are positive about going to the vegetable garden at the school. "We feel good because we are helping the people to eat and care for the environment." Environmental learning takes place in Economic and Management Sciences, Sepedi and Afrikaans, Technology, Social Sciences, Natural Sciences, Life Orientation, Mathematics and Life Skills as subjects where the environment is a focus. There is awareness at the school concerning no littering, saving water ("We must use a cup to drink'cause we waste water, because the people don't have water, so you must save water."), electricity and paper ("always show them how to do pages on both sides"), as well as the celebration of spring and Arbour day as themes of environmental learning. Communication about education for sustainable development creates awareness, showing that stakeholders in the school promote education for sustainable development by making learners aware of the environmental issues at the school. Nongovernmental organisations play important roles in supporting environmental learning at the farm school ("they came to train us how to plant carrot, how to plant cabbage...also helped us how to water the trees outside by planting in bottles with small holes.").

The implementation complexities and difficulties in promoting education for sustainable development are identified as barriers by teachers who are requested by the environmental coordinator to integrate environmental learning into lessons. Teachers are of the opinion that environmental learning does not carry the same weight as the curriculum and the mandate given to teachers by the district office of the department of basic education when work schedules are received. Teachers without a holistic view and knowledge base of cross-curriculum themes require greater change management skills aided by greater communication between teachers on how to integrate environmental learning. The large numbers of learners in a classroom makes experiential learning difficult, and environmental learning is hampered by reluctance to integrate environmental learning because of a lack of knowledge and understanding ("58 children in class ... they step on the plants ... it's really a problem.").

In the urban school there is a commitment to environmental learning and the promotion of education for sustainable development ("learners engage with plants and insects, do measuring 
exercises outside on the quad, use waste to make objects for task work and produced sorting bins as a task project"). The understanding is that environmental learning entails the care and preservation of the environment. This is seen through the teaching and learning in Life Skills in the Foundation phase (recycling projects), and Economic and Management Sciences, Mathematics, in Life Orientation paper turbines were to be made, as well as solar ovens, Social Sciences, Natural Sciences, English, Setswana (themes on water were addressed) and Technology (themes on hygiene and cleanliness of the environment). In the Intermediate and Senior phases, the curriculum and themes identified by the school address environmental issues. Learners apply their knowledge and skills both inside and outside the classroom, using the environment outside for learning purposes (the trees on the premises are marked with numbered signs also indicating their Latin and South African names). Commitment by the stakeholders at the school and communication between teaching and non-teaching staff have alerted the participants in the school to how paper can be saved and recycled (learners are aware of the paper they reuse at school, ensuring that both sides of paper are put to use). In this way it has become common practice for everybody to implement the principles of sustainable development by committing to save, recycle, and so make a difference environmentally and financially. This was all made possible through communication, awareness (teachers and learners are told about recycling and saving of water, as well as to be attentive to littering during staff gatherings, assembly and by means of messages on pin-up boards around the school) and commitment within a whole-school approach to integrating environmental learning into teaching and learning. The non-participant classroom observations in the Foundation phase saw first-hand paper being printed on both sides and that sorting bins were located in the front of the classroom. The document analysis of the environmental committee file reveals that the implementation of waste awareness in teaching and learning was documented in the school commitment and detailed action plan, including the reduction, reuse, recovery and recycling of waste in teaching and learning and school practices.

\section{Comparison}

The indicators identified from each of the three schools are presented in Tables 2-4 below. These indicators represent characteristics noted in the environmental management system of each of the three schools. This article and the study on which it reports aimed to identify indicators that promote education for sustainable development in schools that implement an environmental management system. The indicators noted have been clustered according to the four pillars of sustainable development adapted from John Fien [67].

Sustainable development not only entails an interrelationship between humankind, the environment and financial factors, but more importantly a fourth dimension, namely the role of management, referring to the manner of governance [68]. The different degrees of shading correspond across the three tables to indicate a similarity (cf. Tables 2-4). Despite there not being evidence of an interrelationship between the four pillars in the study, all four are interconnected to ensure sustainable development [67]. The tables therefore indicate the five objectives of environmental education identified for each indicator (cf. Tables $2-4 * \mathrm{~A}=$ Awareness; ${ }^{*} \mathrm{~K}=$ Knowledge; ${ }^{*} \mathrm{At}=$ Attitude; ${ }^{*} \mathrm{~S}=$ Skills; ${ }^{*} \mathrm{P}=$ Participation $)$ and the inclusion of evaluation $\left({ }^{*} \mathrm{E}=\right.$ Evaluation). Environmental learning in schools through curriculum work, school environmental management and community involvement forms part of a whole-school approach [69].

Each pillar of sustainable development has been assigned a colour. The different degrees of shading of each colour correspond across the three tables to indicate a similarity (cf. Tables 2-4). The blocks that are white do not correspond across the three tables and are unique to each type of school. 
Table 2. Indicators of the environmental management system implemented in the township primary school that promotes education for sustainable development.

\begin{tabular}{|c|c|c|c|}
\hline \multicolumn{4}{|c|}{ Township school } \\
\hline Environmental & Social & Economic & Governance \\
\hline Systems thinking $\left({ }^{*} \mathrm{~K}\right)$ & $\begin{array}{l}\text { Communication: } \\
\text { - } \quad \text { Daily assembly with learners }\left({ }^{*} \mathrm{~A}\right) \\
\text { - } \quad \text { Morning briefing }\left({ }^{*} \mathrm{~A}\right) \\
\text { - } \\
\quad \text { hean channel of communication with } \\
\text { - } \quad \begin{array}{l}\text { Knowledge of environmental } \\
\text { management system implemented }\left({ }^{*} \mathrm{~K}\right)\end{array}\end{array}$ & Quintile status-2 (*E) & $\begin{array}{l}\text { Management approach to environmental } \\
\text { management system: } \\
\text { - } \quad \text { Top-down implementation }\left({ }^{*} \mathrm{P}\right) \\
\text { - } \quad \text { Hierarchical management }\left({ }^{*} \mathrm{P}\right) \\
\text { - } \quad \text { Collegial management in education }\left({ }^{*} \mathrm{P}\right) \\
\text { - }\end{array}$ \\
\hline $\begin{array}{l}\text { Low tolerance of litter: } \\
\text { Waste management strategy: refuse } \\
\text { bins every } 20 \mathrm{~m}\left({ }^{*} \mathrm{At}\right)\end{array}$ & $\begin{array}{l}\text { Stakeholders interconnected and share } \\
\text { responsibility }\left({ }^{*} \mathrm{P}\right)\end{array}$ & $\begin{array}{l}\text { Fundraising committee: } \\
\text { - } \quad \text { Recycle plastic bread bags }\left({ }^{*} \mathrm{P}\right) \\
\text { - } \quad \text { Paper recycling }\left({ }^{*} \mathrm{P}\right)\end{array}$ & Whole-school approach to management $\left({ }^{*} \mathrm{P}\right)$ \\
\hline $\begin{array}{l}\text { Save water: } \\
\text { - } \quad \text { Drinking mugs at taps }\left({ }^{*} \mathrm{~A}\right) \\
\text { - } \quad \text { Maintenance repairs to toilets }\left({ }^{*} \mathrm{At}\right)\end{array}$ & Inherent interest in environment $\left({ }^{*} \mathrm{At}\right)$ & $\begin{array}{l}\text { Reusable plastic plates and mugs for } \\
\text { feeding scheme }\left({ }^{*} \mathrm{~K} \&{ }^{*} \mathrm{~A}\right)\end{array}$ & Prioritise environmental management $\left({ }^{*} \mathrm{P}\right)$ \\
\hline $\begin{array}{l}\text { Save electricity: } \\
\text { - } \quad \text { Conscious }\left({ }^{*} \mathrm{At}\right)\end{array}$ & $\begin{array}{l}\text { Raise awareness: } \\
\text { - } \quad 67 \text { minutes for Mandela }\left({ }^{*} \mathrm{P}\right) \\
\text { - } \quad \text { Rain gauge in vegetable garden }\left({ }^{*} \mathrm{~A}\right) \\
\text { - } \quad \text { Water saving awareness board at } \\
\text { entrance to school }\left({ }^{*} \mathrm{~A}\right) \\
\text { - } \quad \text { Dettol hygiene posters }\left({ }^{*} \mathrm{~A}\right) \\
\end{array}$ & & Functional environmental committee $\left({ }^{*} \mathrm{P}\right)$ \\
\hline $\begin{array}{l}\text { Greening: } \\
\text { - } \quad \text { Vegetable garden }\left({ }^{*} \mathrm{~K}\right) \\
\text { - } \quad \text { Indigenous garden }\left({ }^{*} \mathrm{~K}\right)\end{array}$ & $\begin{array}{l}\text { Commitment: } \\
\text { - School pledge for greening mounted on } \\
\text { a school wall }\left({ }^{*} \mathrm{~A}\right)\end{array}$ & & \\
\hline & \begin{tabular}{ll}
\multicolumn{2}{l}{ Hygiene: } \\
- $\quad$ Reinforced $\left({ }^{*} \mathrm{~K}\right)$ \\
- $\quad$ Wash bucket in Foundation phase $\left({ }^{*} \mathrm{At}\right)$
\end{tabular} & & \\
\hline & Behaviourist learning $\left({ }^{*} \mathrm{At}\right)$ & & \\
\hline
\end{tabular}


Table 3. Indicators of the environmental management system implemented in the farm primary school that promotes education for sustainable development.

\begin{tabular}{|c|c|c|c|}
\hline \multicolumn{4}{|c|}{ Farm school } \\
\hline Environmental & Social & Economic & Governance \\
\hline $\begin{array}{l}\text { Greening: } \\
-\quad \text { Vegetable garden }\left({ }^{*} \mathrm{~K}\right) \\
\text { - } \quad \text { Indigenous garden }\left({ }^{*} \mathrm{~K}\right)\end{array}$ & $\begin{array}{l}\text { Communication: } \\
\text { - } \quad \text { Action plans }\left({ }^{*} \mathrm{At}\right) \\
\text { - } \quad \text { Knowledge and understanding of } \\
\text { environmental management system }\left({ }^{*} \mathrm{~K}\right)\end{array}$ & Quintile status-1 $\left({ }^{*} \mathrm{E}\right)$ & $\begin{array}{l}\text { Environmental committee } \\
\text { duties }\left({ }^{*} \mathrm{P}\right)\end{array}$ \\
\hline $\begin{array}{l}\text { Save electricity: } \\
\text { - } \quad \text { Daylight switch }\left({ }^{*} \mathrm{At}\right)\end{array}$ & $\begin{array}{l}\text { Raise awareness: } \\
\text { - } \quad \text { Of action plans }\left({ }^{*} \mathrm{~A}\right) \\
\text { - } \quad \text { Newspaper clippings and learners' } \\
\quad \text { posters used as resources }\left({ }^{*} \mathrm{~A}\right)\end{array}$ & $\begin{array}{l}\text { Reusable plastic plates and mugs at } \\
\text { feeding scheme }\left({ }^{*} K \&{ }^{*} A\right)\end{array}$ & $\begin{array}{l}\text { Influence of stakeholders in } \\
\text { management }\left({ }^{*} \mathrm{P}\right)\end{array}$ \\
\hline $\begin{array}{l}\text { Save water: } \\
\text { - } \quad \text { Irrigation mechanism }\left({ }^{*} \mathrm{At}\right) \\
\text { - } \quad \text { Holding tank on tower }\left({ }^{*} \mathrm{At}\right) \\
\text { - } \quad \text { Drinking taps spillage runs into } \\
\text { flower beds }\left({ }^{*} \mathrm{At}\right) \\
\text { - } \quad \text { Water harvesting }\left({ }^{*} \mathrm{~A}\right)\end{array}$ & & $\begin{array}{l}\text { Limit placed on: } \\
\text { - } \quad \text { Paper for printing }\left({ }^{*} \mathrm{~K} \& \mathrm{~A}\right) \\
\text { - } \quad \text { Toilet paper }\left({ }^{*} \mathrm{~K} \&{ }^{*} \mathrm{~A}\right)\end{array}$ & \\
\hline Compost heap $\left({ }^{*}\right)$ & & & \\
\hline Low tolerance of litter $\left({ }^{*} \mathrm{At}\right)$ & & & \\
\hline Bicycle transport $\left({ }^{*} \mathrm{~A}\right)$ & & & \\
\hline $\begin{array}{l}\text { Environmental calendar days are } \\
\text { celebrated }\left({ }^{*} \mathrm{~A}\right)\end{array}$ & & & \\
\hline
\end{tabular}

${ }^{*} \mathrm{~A}=$ Awareness $;{ }^{*} \mathrm{~K}=$ Knowledge $;{ }^{*} \mathrm{At}=$ Attitude $;{ }^{*} \mathrm{~S}=$ Skills; ${ }^{*} \mathrm{P}=$ Participation; ${ }^{*} \mathrm{E}=$ Evaluation. 
Table 4. Indicators of the environmental management system implemented in the urban primary school that promotes education for sustainable development.

\begin{tabular}{|c|c|c|c|}
\hline \multicolumn{4}{|c|}{ Urban School } \\
\hline Environmental & Social & Economic & Governance \\
\hline Systemic thinking and communication $\left({ }^{*} \mathrm{~K}\right)$ & $\begin{array}{ll}\text { Communication used: } \\
\text { - } & \text { To raise awareness }\left({ }^{*} \mathrm{~A}\right) \\
\text { - } & \text { By two environmental coordinators }\left({ }^{*} \mathrm{P}\right) \\
\text { - } & \text { Messages on walls and windows }\left({ }^{*} \mathrm{~A}\right) \\
\text { - } & \text { Weekly newsletter }\left({ }^{*} \mathrm{~A}\right) \\
\text { - } & \text { Hygiene posters with soap in toilets }\left({ }^{*} \mathrm{~A}\right)\end{array}$ & Quintile status-4 $\left({ }^{*} \mathrm{E}\right)$ & $\begin{array}{l}\text { Management: } \\
\text { - Headmaster: lack of participation and } \\
\text { delegating style of management }\left({ }^{*} \mathrm{P}\right) \\
\text { - } \quad \text { Governing body: lack of communication }\left({ }^{*} \mathrm{P}\right)\end{array}$ \\
\hline $\begin{array}{ll}\text { 3R campaign: }\left({ }^{*} \text { At } \&{ }^{*} \mathrm{~S}\right) \\
\text { - } & \text { Limit paper use }\left({ }^{*} \mathrm{~K} \&{ }^{*} \mathrm{~A}\right) \\
\text { - } & \text { Two sorting bins per classroom } \\
\text { - } & \text { Four sorting bins outside stationary } \\
& \text { shop }\left({ }^{*} \mathrm{At}\right) \\
\text { - } & \text { Grade Rs reusable containers and } \\
& \text { shrubs in old tyres }\left({ }^{*} \mathrm{At} \&{ }^{*} \mathrm{~S}\right) \\
\text { - } & \text { Waste battery harvesting }\left({ }^{*} \mathrm{~A}\right) \\
\text { - } & \text { Printing room has special boxes for } \\
& \text { cartridges, waste paper and reusable } \\
& \text { paper }\left({ }^{*} \mathrm{~K},{ }^{*} \mathrm{At} \&{ }^{*} \mathrm{~A}\right)\end{array}$ & $\begin{array}{l}\text { Awareness: } \\
\text { - } \quad \text { Whole-school }\left({ }^{*} \mathrm{~A}\right) \\
\text { - } \\
\text { Examples of tasks related to environmental } \\
\text { - } \quad \text { Functional media resource centre }\left({ }^{*} \mathrm{~K} \&{ }^{*} \mathrm{~A}\right) \\
\text { - } \quad \text { Aesthetic waste bins }\left({ }^{*} \mathrm{~K} \&{ }^{*} \mathrm{~A}\right) \\
\text { - } \quad \text { Dettol hygiene posters }\left({ }^{*} \mathrm{~K} \&{ }^{*} \mathrm{~A}\right) \\
\text { - } \\
\quad \text { anvironmental dates calendar in classroom } \\
\text { - } \quad \text { Learners' service chart }\left({ }^{*} \mathrm{~A} \mathrm{~A}\right)\end{array}$ & $\begin{array}{l}\text { Geyser's temperature turned } \\
\text { down to } 55^{\circ} \mathrm{C}\left({ }^{*} \mathrm{~K}\right)\end{array}$ & $\begin{array}{l}\text { Whole-school approach to education for } \\
\text { sustainable development }\left({ }^{*} \mathrm{P}\right)\end{array}$ \\
\hline $\begin{array}{l}\text { Save electricity: } \\
\text { - Energy saver globes }\left({ }^{*} \mathrm{At}\right)\end{array}$ & $\begin{array}{l}\text { Hygiene: } \\
\text { - Foundation phase wash buckets }\left({ }^{*} \mathrm{~K}\right)\end{array}$ & Second-hand clothing store $\left({ }^{*} \mathrm{~K}\right)$ & $\begin{array}{l}\text { Environmental committee file follows guideline } \\
\text { from project environmental management system } \\
\text { workshop }\left({ }^{*} \mathrm{P}\right)\end{array}$ \\
\hline $\begin{array}{l}\text { Save water: } \\
\text { - Irrigation strategies }\left({ }^{*} \mathrm{At}\right)\end{array}$ & Behaviourist learning $\left({ }^{*} \mathrm{At}\right)$ & $\begin{array}{l}\text { Limit placed on: } \\
\text { - } \quad \text { Paper for printing }\left({ }^{*} \mathrm{~K} \&{ }^{*} \mathrm{~A}\right) \\
\text { - } \quad \text { Toilet paper }\left({ }^{*} \mathrm{~K} \&{ }^{*} \mathrm{~A}\right)\end{array}$ & \\
\hline $\begin{array}{l}\text { Greening: } \\
-\quad \text { Indigenous trees }\left({ }^{*} \mathrm{~K}\right)\end{array}$ & & & \\
\hline Railings around lawn $\left({ }^{*} \mathrm{~A}\right)$ & & & \\
\hline Pine gel detergents $\left({ }^{*} \mathrm{~K}\right)$ & & & \\
\hline
\end{tabular}


A comparison of the three schools shows that the integration of environmental management in each is connected to the type of school and the circumstantial meaning it ascribes to sustainable development as a result of its environment and situation. Low tolerance of litter in the township and farm schools is deemed most important whereas all three schools deemed greening (vegetable \& indigenous gardens/trees), and saving water and electricity as important (indicators of the environmental management system). Systemic thinking also features as an indicator that with communication will allow learners to understand how related elements organise into a complex whole. This is especially true in the urban school, where attitudes and skills are acquired through the reduce, reuse and recycle (3R) campaign. Regarding social indicators, communication of school action plans, knowledge and understanding of the environmental management system, as well as the raising of awareness feature strongly in all three schools. Behaviourist learning features strongly in the township and urban school as a means to obtain a change in learner attitude toward their immediate environment. In the township school stakeholders share responsibility and an inherent interest in the environment showing the importance of participation and attitude toward the integration of an environmental management system in a school. Commitment towards environmental management is also deemed important and creates a greater awareness. Both the township and urban school deem hygiene as important with regard to sharing knowledge about our environment.

The economic indicators that play a role in the environmental management system include the quintile status of each school. This refers to the poverty score based on the relative poverty of the community in which each school is located. The lowest $40 \%$ (quintiles 1-farm and 2-township) are deemed poor and quintile 5 schools are the least poor. Government funds the expenses that were previously covered by fees [70].

It is evident that the quintile status influences the reuse of items, recycling of others and reduction of consumption in all three schools. It has become evident that management is an important feature when implementing an environmental management system. The management approach to environmental management system ought to include a whole-school approach to management where participation is crucial and environmental management is prioritised amongst the environmental committee and other stakeholders in the school.

\section{Discussion}

The core components of what an environmental management system framework could look like to promote education for sustainable development in three South African primary schools will be discussed. A brief explanation and analysis of each of the three schools, in the form of a general discussion will reveal further indicators that an environmental management system framework could include to promote education for sustainable development in the three South African primary schools. The township school is characterised by socioeconomic factors and an organisational structure within a semi-functional whole-school approach to promote education for sustainable development. The environmental management system was semi-functional because not all the stakeholders were aware of the environmental management system at their school. There is, however, awareness and knowledge of environmental learning amongst learners, and teachers do promote environmental learning in their teaching and learning because it is part of the curriculum. The interviews revealed that the governing body, community member, learners and administrative staff member did not have any knowledge of the environmental management system implemented at the school for almost two years, showing that the governing body lacks knowledge management. Knowledge management communication is not functioning between stakeholders with regard to environmental management, and needs to be prioritised in the school since awareness of environmental management can lead to the process of capturing and making use of an organisation's collective expertise and everyone can contribute to effective environmental management in the school. The socioeconomic factors of the area that the school finds itself in has also influenced its consciousness of hygiene as a theme. Of significance is the commitment declaration and environmental policy drawn up by the headmaster 
and environmental coordinator, who are both Geography teachers and have management qualifications. It reflects systems thinking from two individuals who have knowledge of a subject that studies the interrelationships between humankind and their environment, by acknowledging the school's pledge to a positive response to nature's demand to uphold greening as a symbol and commitment to support life and stabilize the co-existence of other member of the ecosystem.

The township school's management does view the school as a whole, but treats it as individual components. The school as a whole is not aware of its different components, owing to the fact that governing body chair does not know about the environmental management at the school. The same applies to new staff members joining the school who, one can deduce, are not being informed of the environmental management system. There must therefore be constant communication between the components of the system.

The farm school is characterised by an environmental management system managed together with health promotion, and by a multitasking environmental coordinator within a hierarchical school structure. The knowledge management process in the farm school does not function optimally. Teachers were approached to implement environmental learning, but no evidence exists of follow-up communication. What is deduced from the workload of the environmental coordinator is that his duties (Head of Department of two phases, teacher and member of committees) are factors responsible for the lack of dissemination and flow of knowledge creation, collection, organisation, refinement, dissemination, and maintenance. The school's culture is such that the lack of open communication between staff members needs to be overcome by a change in attitudes and behaviours in sharing their knowledge and not accumulating it. The teachers find themselves in a school with an authority and obedience type manager who acts in a command and control manner that is not conducive to the implementation of an environmental management system where there needs to be more communication and collaborative work amongst colleagues. These are typical barriers to environmental management system implementation called organisational culture and communication barriers.

In the farm school a clear hierarchical model of education management exists on two levels. Firstly, the headmaster follows a hierarchical model of management and the staff follows a culture of non-participation. Secondly, the teachers and the headmaster feel that they are responsible to higher powers, being the district office of the department of basic education and the national education policy, therefore promoting teaching and learning, and correctly so, and then dealing with environmental management. In the farm school the headmaster has approached environmental management implementation together with a health promotion programme (a request by the department of basic education). It is a fact that in this farm school the natural resources play an important part in the functioning of the school and will continue to be important to themes of focus.

The urban school's environmental management system is characterised by committed environmental coordinators who create awareness and maintain communication flow through change management. The urban school has followed the systems theory of management because the school has proved in its choice of the 3R campaign as theme that it is interrelated and interdependent in its manner of getting all the stakeholders behind the same cause. The $3 \mathrm{R}$ campaign created a balance and ensured that everybody on the school property worked toward achieving the set goals. Of significance is that the two environmental coordinators maintain an effective and continuous flow of communication amongst stakeholders. An information sheet is given to new teachers to inform them about environmental management in the school. The environmental coordinators encouraged the open and continuous channel of communication within the school. The fact that they reminded teachers to include environmental learning into their teaching and learning regularly, spoke with the administration staff and cleaning staff, and garden staff through the factotum/Intermediate phase teacher, led to these individuals thinking and acting together about promoting sustainable development. Their initiative led to team learning and promoted systems thinking because especially the administration and cleaning staff who also did photocopying realised that their actions can make a 
difference, not only environmentally but financially too. The school made use of experiential learning as a learning theory for education for sustainable development and so plays an important role in learners' development by allowing for a hands-on learning experience. Despite the school commitment to integrating environmental learning into teaching and learning was fulfilled, and implementing an environmental management system, commitments have been standing for two years and an evaluation has not been undertaken.

The core components of what an environmental management system framework could look like to promote education for sustainable development in three South African primary schools are based on the research at the three schools. Even though each case in this multiple case study is unique-a township, farm, and urban school-the components of the framework fit the individual cases, being primary schools. Despite a case study's limitation regarding generalisabilty, much can be learned from one particular case and in this study it was from three primary schools. The environmental management system framework must be centred on general management strategies (an outer foundational core), as well as environmental learning and the curriculum that is applicable to all schools [47].

The outer foundational core is made up of the four pillars of sustainable development (cf. Figure 1). There must be continuous communication and flow of information between all the stakeholders and management stages in both sections of the framework, where communication skills, knowledge and understating of the interaction between and with the curriculum and management, as well as attitudes and values of stakeholders must be conducive to promoting education for sustainable development. Yearly planning must be undertaken. The school must commit, formally adopt and implement the environmental management system. The implementation of the action plan involves setting objectives that require yearly review. Schools will decide how many themes they can accommodate in a year and year-on-year the old and new themes may run concurrently, so as to maintain sustainability and continuity. Stakeholders will be invited to take part and they will plan the implementation of the action plan, be responsible for its implantation in teaching and learning or throughout the school as organisation. The ideal, for the success of implementing an environmental management system, is to implement a double, top-down and bottom-up approach. The top-down approach refers to the environmental committee and the bottom-up one refers the stakeholders to whom the implementation has been delegated with the cooperation and participation of the environmental committee. The ideal effect for promoting education for sustainable development is that there will be greater participation of stakeholders and it will promote feedback. The environmental committee needs to maintain operational control. Source-directed instruments can be used (behaviour-directed slogans around the school or messages of awareness creation at assembly). It is important to monitor the environmental performance of the stakeholders in the teaching and learning and in the environmental management. Effect-directed instruments can also be monitored for practicality and effectivity (rain harvesting). The environmental management system must be evaluated on a yearly basis. The literature refers specifically to audits, measuring and reviewing as being necessary requirements of an environmental management system. This is to ensure that corrective action can take place and so that the environmental policy can be revised to amend the sustainable journey that the school finds itself in. The evaluation exercise is necessary so that the environmental management system can be tailored for each school and so that sustainability of the environmental management system can be ensured. 


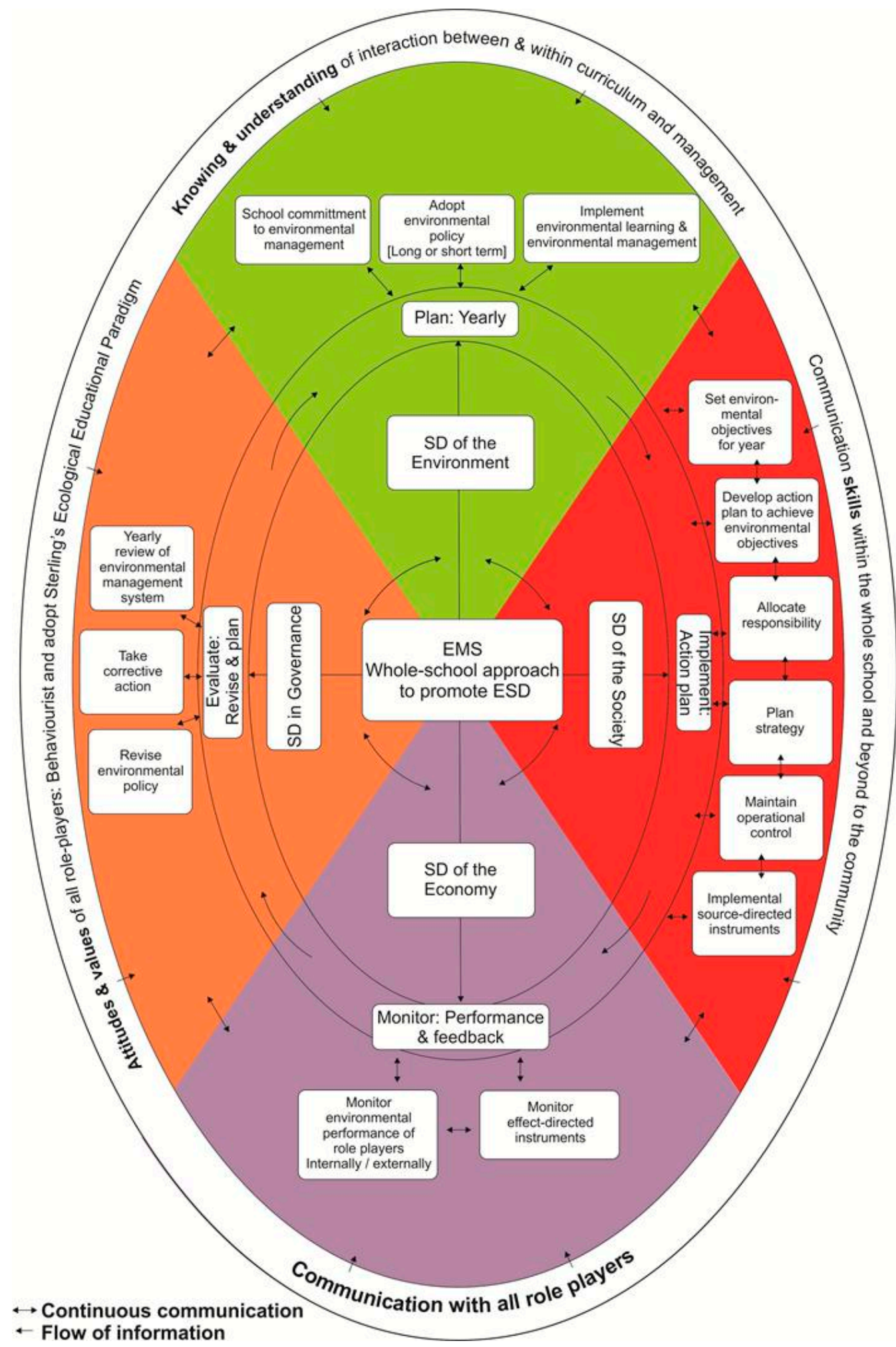

Figure 1. The environmental management system framework, showing a whole-school approach to promoting education for sustainable development.

It is important that the township, farm and urban school, and primary schools that find themselves in similar contexts, must be aware of the impact of their socioeconomic situation (quintile status) and number of learners in the class that influences the practicality of, for example, experiential 
learning. Environmental management system organisational barriers that require attention and that are sidestepped are organisational structure, top management commitment, lack of communication in environmental management system implementation and communication, organisational culture, strategy integration, strategy complexity, and management style. It is suggested that, when the framework is implemented, change management skills that are learned through experience in order to flourish be used. The reason is that the yearly evaluation by the environmental committee will direct the schools focus and so the school will be required to adapt to new ways of operating. It will make them grow in knowledge and skills and change the behaviours of the stakeholders' experiential learning. Again, all the stakeholders could also apply systemic and holistic thinking practices to their duties. In this way a relationships will exist between systems theory and the implementation of an environmental management system in a school organisation as a system.

The environmental management system must be based on a whole-school approach to promoting education for sustainable development. The stakeholders in the school must all have knowledge and understanding of the environmental management system, as well as apply systemic and holistic thinking skills. It is recommended that environmental learning promote holistic thinking within themes in place and time, using local, national, regional, international and global scale thinking; knowledge and understanding acquisition, skill development, and values and attitude competencies; human and environmental relations, economic dimensions, decision-making and sustainable behaviours; and a systemic approach that is based on experiential learning.

Education in its traditional form is not enough to meet the challenges of unsustainable living [71,72]. Education in the twenty-first century is more than knowledge reproduction. In a South African context it may promote changes in behaviour, despite international reports of a very limited success of a dominant search for behavioural change at an individual level [73]. Education could also promote changes in life styles and values, among others. All of this is necessary so as to achieve sustainable development for the survival of humankind. New educational approaches are therefore suggested as necessary in order to guide life style changes that will help in developing a new ecological vision and an awareness of global solidarity [47].

\section{Conclusions}

The implementation of an environmental management system framework for primary schools is characterized by the whole-school approach to education for sustainable development at a local level closest to implementation with stakeholders engagement [8]. The Global Action Program [72] endorses the promotion of whole-school approaches to education for sustainable development and requires a reorientation of teaching content and methodology, in line with sustainable development, and management practices. The environmental management system framework designed is significant because it not only addresses a South African aim to promote education for sustainable development, it fulfils the international call of UN to promote education for sustainable development-the World Summit on Sustainable Development's Summit Plan of Implementation that encourages the improvement of social and environmental performance through an environmental management system [74] and the sustainable development goals are also fulfilled [9]. It also calls for the integration of sustainable development into education systems at all levels of education so that education can act as an agent for change through sustainable management school practices [9]. Similarly, research has also shown that an environmental management system is helpful in education for sustainable development. It leads to changes in group knowledge, skills and actions. Environmental characteristics integrated into extracurricular school activities and into the strategic visions of the management of the schools showed varying levels of success [75].

The purpose of this research was to get schools to implement an environmental management system and use it as a governance tool to promote education for sustainable development as proposed by the UN. It is the opinion of the authors that a holistic and interdisciplinary approach to environmental education is necessary. Education plays a central role in the promotion of what 
Sauvé [42] termed environmental education for sustainable development [49,76] especially since the Brundtland report held a holistic and systemic view of issues pertaining to the environment and development. Since the UN declarations and meetings promote systemic thinking skills in environmental education and especially the integration of teaching and learning in education as an essential and practical part of environmental management, the opinion of the authors is that the four pillars of sustainable development endorse education for sustainable development and, the objectives of environmental education remain nested in an environmental management system.

Acknowledgments: The project was equally supported by the Gauteng and North West Provincial Departments of Basic Education in South Africa, the Flemish education department as sponsor. A word of thanks is due to the German Academic Exchange Service (DAAD) in partnership with the National Research Foundation (NRF) for the financial assistance towards this research. Opinions expressed and conclusions arrived at, are those of the author and are not necessarily to be attributed to the NRF.

Author Contributions: Luiza de Sousa undertook the research study and analysed the data; Barry Richter and Schalk Raath validated the data; Luiza de Sousa, Barry Richter and Schalk Raath wrote the paper.

Conflicts of Interest: The authors declare no conflict of interest.

\section{References}

1. Andersson, K. Starting the pluristic tradition of teaching? Effects of education for sustainable development (ESD) on pre-srvice teachers' views on teaching about sustainable development. Environ. Educ. Res. 2017, 23, 436-449. [CrossRef]

2. Lotz-Sisitka, H.B. Environmental education and training in industry: An introductory overview of some developments in South Africa. In Environmental Education: Some South African Perspectives; Loubser, C.P., Ed.; Van Schaik: Pretoria, South Africa, 2005; pp. 162-173.

3. Wals, A.E.J.; Geerling-Eijff, F.; Hubeek, F.; van der Kroon, S.; Vader, J. All mixed up? Instrumental and emancipatory learning toward a more sustainable world: Considerations for EE policymakers. Appl. Environ. Educ. Commun. 2008, 7, 55-65. [CrossRef]

4. Naidu, A.; Joubert, R.; Mestry, R.; Mosoge, J.; Ngcobo, T. Education Management and Leadership: A South African Perspective; Oxford University Press: Cape Town, South Africa, 2008.

5. Anon. Township. Encarta Dictionary, [CD-ROM] 2005. Microsoft@Encarta®Premium Suite 2005 (C) 1993-2004; Microsoft Corporation: Redmond, WA, US, 2005.

6. Mattson, E.; Harley, K. Teacher identities and strategic mimicry in the policy/practice gap. In Changing Patterns of Teacher Education in South Africa: Policy, Practice and Prospects; Lewin, K., Samuel, M., Sayed, Y., Eds.; Heinemann: Cape Town, South Africa, 2002; pp. 284-305.

7. Hens, L.; Wiedemann, T.; Raath, S.P.; Renders, P.; Craenhals, E.; Richter, B.W. Capacity Building for Environment Learning and Sustainable Living: Environmental Management Systems in Schools in South Africa; Novinka: New York, NY, USA, 2011.

8. Kanie, N.; Abe, N.; Iguchi, M.; Yang, J.; Kabiri, N.; Kitamura, Y.; Mangagi, S.; Miyazawa, I.; Olsen, S.; Tasaki, T.; et al. Integration and diffusion in sustainable development goals: Learning from the past, looking into the future. Sustainability 2014, 6, 1761. [CrossRef]

9. UN. Transforming Our World: The 2030 Agenda for Sustainable Development. 2015. Available online: https:/ / sustainabledevelopment.un.org/post2015/transformingourworld (accessed on 13 March 2017).

10. UNEP. Global Environmental Outlook 2000. Available online: http:/ / www.unwp.org/Geo2000/english/ 0058.htm (accessed on 12 April 2017).

11. Coglianese, C. Measuring Regulatory Performance: Evaluating the Impact of Regulation and Regulatory Policy. Available online: https://www.oecd.org/gov/regulatory-policy/1_coglianese\%20web.pdf (accessed on 15 May 2017).

12. South Africa. Department of Education. White Paper on Education and Training. Available online: http:/ / www.gov.za/sites/www.gov.za/files/16312_gen196_0.pdf (accessed on 15 May 2017).

13. South Africa. National Environmental Management Act (NEMA). Available online: https://www.environment.gov.za/sites/default/files/legislations/nema_amendment_act107.pdf (accessed on 15 May 2017). 
14. Hens, L.; Wiedemann, T.; Raath, S.; Stone, R.; Renders, P.; Craenhals, E. Performance of newly implemented environmental management systems in primary schools in south africa. J. Environ. Manag. 2010, 91, 906-917. [CrossRef] [PubMed]

15. Sleurs, W. Competencies for Education for Sustainable Development Teachers: A Framework to Integrate ESD in the Curriculum of Teacher Training Institutes. Available online: http://www.unece.org/ fileadmin/DAM/env/esd/inf.meeting.docs/EGonInd/8mtg/CSCT\%20Handbook_Extract.pdf (accessed on 13 February 2017).

16. Van Rooyen, E.J.; Naidoo, R.R. Utilising environmental management systems to address municipal sustainable development. J. Public Adm. 2008, 43, 736-748.

17. Steger, U. Environmental management systems: Empirical evidence and further perspectives. Eur. Manag. J. 2000, 18, 23-37. [CrossRef]

18. Emblemsvåg, J.; Bras, B. Activity-Based Cost and Environmental Management: A Different Approach to the ISO 14000 Compliance; Kluwer Academic Publishers: Boston, MA, USA, 2001.

19. Heras, I.; Arana, G. Alternative models for environmental management in SMEs: The case of Ekoscan vs. ISO 14001. J. Clean. Prod. 2010, 18, 726-735. [CrossRef]

20. UN. United Nations Report on the World Summit for Sustainable Development Plan of Implementation. 2002. Available online: http://www.un.org/jsummit/html/documents/summit_docs/2309_planfinal.htm (accessed on 2 September 2016).

21. Renders, P. The Flemish MOS-project (Milieuzorg op school): How to put theoretical environmental education into practice. Unpublished work. 2005.

22. Craenhals, E. MOS-Handleiding; COLOFON: Brussels, Belgium, 2010.

23. Eco-Schools. About Eco-Schools. 2014. Available online: http://www.ecoschools.global/how-does-it-work/ (accessed on 12 April 2017).

24. Eco-Schools. Eco-Schools Programme Brochure; International Eco-School Coordination: Lisbon, Portugal, 2010.

25. SEED. Sustainability and Environmental Education. 2016. Available online: http://se-ed.co.uk/edu/ sustainable-schools / (accessed on 11 April 2017).

26. DCSF. Department for Children, Schools and Families Sustainable Schools: A Brief Introduction 2008. Available online: http://www.se-ed.co.uk/sites/default/files/resources/Framework\%20Resource.pdf (accessed on 11 April 2017).

27. Von Lüpke, G.; Tapia, I.E.; Blochmann, G.E. Environmental education in Germany: Concepts, history, projects, visions. Bild. Wiss. 2000, 4, 1-32.

28. De Haan, G. The blk '21' programme in Germany: A 'gestaltungskompetenz'-based model for education for sustainable development. Environ. Educ. Res. 2006, 12, 19-32. [CrossRef]

29. Sommer-Guist, C. Teaching and Learning Sustainably. Available online: https://www.goethe.de/de/kul/ ges.html (accessed on 11 April 2017).

30. UNESCO. Education for Sustainable Development in Germany. 2010. Available online: http:/ / www.bneportal.de/coremedia/generator/unesco/en/01_Home/English_20Homepage.html (accessed on 10 December 2010).

31. Bork, H.R.; Hemmer, I.; Czapek, F. Educational Standards in Geography for the Intermediate School Certificate with Sample Assignments, 2nd ed.; German Geographical Society: Bonn, Germany, 2012.

32. Raath, S.P.; Stone, A.B.; van Heerden, M.F.D. Environmental management for sustainable living in schools. Unpublished work, 2004.

33. Raath, S.P.; Stone, A.B.; van Heerden, M.F.D. Education for sustainable living: Guideline book. Unpublished work, 2009.

34. Nel, J.G.; Kotzé, L.J. Environmental management: An Introduction. In Environmental Management in South Africa, 2nd ed.; Strydom, H.A., King, N.D., Eds.; Juta: Cape Town, South Africa, 2009; pp. 1-33.

35. Barrow, C.J. Environmental Management for Sustainable Development, 2nd ed.; Routledge: Oxon, UK, 2006.

36. UNESCO-UNEP. Final Report, Intergovernmental Conference on Environmental Education. 1977. Available online: http:/ / unesdoc.unesco.org/images/0003/000327/032763eo.pdf (accessed on 16 May 2017).

37. UNESCO. Education for Sustainability. From Rio to Johannesburg: Lessons Learnt from a Decade of Commitment; UNESCO: Paris, France, 2002. 
38. Henderson, K.; Tilbury, D. Whole-School Approaches to Sustainability: An International Review of Sustainable School Programs; Report Prepared by the Australian Research Institute in Education for Sustainability (Aries) for the Department of the Environment and Heritage, Australian Government; Macquarie University: Sydney, Australia, 2004.

39. Tilbury, D. Environmental education for sustainability: Defining the new focus of environmental education in the 1990s. Environ. Educ. Res. 1995, 1, 195-212. [CrossRef]

40. UNESCO. UN Decade of Education for Sustainable Development 2005-2014. Available online: http:/ / unesdoc.unesco.org/images/0014/001416/141629e.pdf (accessed on 16 May 2017).

41. UNESCO. United Nations Decade of Education for Sustainable Development 2005-2014: Draft International Implementation Scheme; UNESCO: Paris, France, 2004.

42. Sauvé, L. Environmental education and sustainable development: A further appraisal. Can. J. Environ. Educ. 1996, 1, 7-34.

43. UNESCO-UNEP. The Tbilisi Communiqué: Educate Today for a Sustainable Future. Outcome Document Adopted at TBILISI+35. Available online: http://www.aaee.org.au/wp-content/uploads2/2009/07/TbilisiCommunique.pdf (accessed on 16 May 2017).

44. UN. The Future We Want: Outcome Document Adopted at Rio+20; United Nations: New York, NY, USA, 2012.

45. UNESC. Learning for the Future: Competencies in Education for Sustainable Development. Available online: https://www.unece.org/fileadmin/DAM/env/esd/ESD_Publications/Competences_Publication. pdf (accessed on 16 May 2017).

46. Van Rooyen, H.G.; de Beer, J. Taking apart or putting together? Systems teaching-learning in ESD. In Proceedings of the 4th World Environmental Education Congress, Durban, South Africa, 2-6 July 2007.

47. De Sousa, L.O. Promoting Education for Sustainable Development: An Environmental Management Systems Framework for South African Primary Schools. Ph.D. Thesis, North-West University, Potchefstroom, South Africa, 2013.

48. Cloud, J.P. Some systems thinking concepts for environmental educators during the decade of education for sustainable development. Appl. Environ. Educ. Commun. 2005, 4, 225-228. [CrossRef]

49. Sterling, S. Whole Systems Thinking as a Basis for Paradigm Change in Education: Explorations in the Context of Sustainability. Ph.D. Thesis, University of Bath, Bath, UK, 2003.

50. Sterling, S. Riding the storm: Towards a connective cultural consciousness. In Social Learning towards a Sustainable World: Principles, Perspectives and Praxis; Wals, A.E.J., Ed.; Wageningen Academic Publishers: Wageningen, The Netherlands, 2007; pp. 63-82.

51. Berk, L.E. Child Development, 7th ed.; Pearson: Boston, MA, USA, 2006.

52. Berger, K.S. The Developing Person: Through Childhood and Adolescence, 6th ed.; Worth Publishers: New York, NY, USA, 2003.

53. Bronfenbrenner, U. Environments in developmental perspective: Theoretical and operational models. In Measuring Environment across the Life Span: Emerging Methods and Concepts; Friedman, S., Wachs, T., Eds.; American Psychological Association Press: Washington, WA, USA, 1999; pp. 3-28.

54. Chisholm, J.; Warman, G. Experiential learning in change management. In The Handbook of Experiential Learning; Silberman, M., Ed.; Pfeiffer: San Francisco, CA, USA, 2007; pp. 321-340.

55. Ball, S.J. Management as moral technology: A Luddite analysis; Routledge: London, UK, 1990.

56. Merriam, S.B.; Tisdell, E.J. Qualitative Research: A Guide to Design and Implementation, 4th ed.; Wiley: San Francisco, CA, USA, 2016.

57. Rule, P.; John, V. Your Guide to Case Study Research; Van Schaik: Pretoria, South Africa, 2011.

58. Yin, R.K. Case Study Research: Design and Methods, 5th ed.; Sage: Thousand Oaks, CA, USA, 2014.

59. Burger, D. South Africa and Its People; Government Communication and Information System: Pretoria, South Africa, 2011.

60. O'Donoghue, T. Planning Your Qualitative Research Project: An Introduction to Interpretivist Research in Education; Routledge: London, UK, 2007.

61. Leedy, P.D.; Ormrod, J.E. Practical Research: Planning and Design, 8th ed.; Prentice-Hall: Upper Saddle River, NJ, USA, 2005.

62. Saldaňa, J. The Coding Manual for Qualitative Researchers; Sage: London, UK, 2009.

63. Johnson, B.R. Examining the validity structure of qualitative research. Education 1997, 118, 282-292.

64. Guest, G.; Bunce, A.; Johnson, L. How many interviews are enough? Field Methods 2006, 18, 59-82. [CrossRef] 
65. Morrell, P.D.; Carroll, J.B. Conducting Educational Research: A Primer for Teachers and Administrators; Sense Publishers: Rotterdam, The Netherlands, 2010.

66. Nieuwenhuis, J.; Smit, B. Qualitative research. In Doing Social Research: A Global Context; Wagner, C., Kawulich, B., Garner, M., Eds.; McGraw-Hill Higher Education: London, UK, 2012; pp. 124-1139.

67. UNESCO. Teaching for a Sustainable World: A Multimedia Teacher Education Programme. Available online: http:/ / www.unesco.org/education/tlsf/mods/theme_a/mod04.html?panel=1\#top (accessed on 8 March 2017).

68. McArthur, J.W.; Sachs, J.D. Report from the International Commission on Education for Sustainable Development Practice; Earth Institute at Columbia University: New York, NY, USA, 2008.

69. Schudel, I.; Roux, C.1.; Lotz-Sisitka, H.; Loubser, C.; O'Donoghue, R.; Shallcross, T. Contextualising learning in advanced certificate in education (environmental education) courses: Synthesising contexts and experiences. S. Afr. J. Educ. 2008, 28, 543-559.

70. Nikiwe, N. (Ed.) Education and Training Unit. Education Policy: School Fees. Available online: http:/ / www.etu.org.za/toolbox/docs/government/schoolfees.html (accessed on 28 November 2016).

71. Maclean, R. Preface. In Environment, Education and Society in the Asia Pacific: Local Traditions and Global Discourses; Yencken, D., Fien, J., Sykes, H., Eds.; Routledge: London, UK, 2005; pp. xii-xvi.

72. UNESCO. Roadmap for Implementing the Global Action Programme on Education for Sustainable Development; UNESCO: Paris, France, 2014.

73. Newig, J.; Schulz, D.; Fischer, D.; Hetze, K.; Laws, N.; Lüdecke, G.; Rieckmann, M. Communication regarding sustainability: Conceptual perspectives and exploration of societal subsystems. Sustainability 2013, 5, 2976. [CrossRef]

74. UN. Report of the World Summit on Sustainable Development: Johannesburg, South Africa; United Nations: New York, NY, USA, 2002.

75. Kanyimba, A.T.; Richter, B.W.; Raath, S.P. The effectiveness of an environmental management system in selected South African primary schools. J. Clean. Prod. 2014, 66, 479-488. [CrossRef]

76. World Commission on Environment and Development. Our Common Future. Report Published as Annex to Document A/42/427: Development and International Co-Operation: Environment Transmitted to General Assembly. Available online: http:/ / www.un-documents.net/wced-ocf.htm (accessed on 2 September 2016). 